DOI: https://doi.org/10.47405/mjssh.v6i11.1177

\begin{tabular}{|c|c|}
\hline 4.581 & Malaysian Journal of Social Sciences and Humanities (MJSSH) \\
\hline $\begin{array}{l}\text { Malaysian Journal of } \\
\text { Social cciences and }\end{array}$ & Volume 6, Issue 11, November 2021 \\
\hline (MJ-SSH) & e-ISSN : 2504-8562 \\
\hline & $\begin{array}{l}\text { Journal home page: } \\
\text { www.msocialsciences.com }\end{array}$ \\
\hline
\end{tabular}

\title{
The Resilience of Unwed Pregnant Teenagers: A Preliminary Survey at Malaysian Women's Shelter Homes
}

\author{
Nurhazlina Mohd Ariffin ${ }^{1}$, Mohamad Shahbani Sekh Bidin'1, Fuziah Shaffie ${ }^{1}$ \\ ${ }^{1}$ School of Applied Psychology, Social Work \& Policy, Universiti Utara Malaysia, \\ 06010 UUM Sintok, Kedah Darul Aman, Malaysia
}

Correspondence: Mohamad Shahbani Sekh Bidin (mohamad.shahbani@gmail.com)

\begin{abstract}
Unwed pregnant teenagers tend to experience various problems. Apart from that, they also receive negative perception from community. For that reason, most shelters are provided to assist and protect the teenagers involved. However, only those who can adjust to hardships or resilient can survive the worse. This preliminary survey aimed to identify the level of resilience among unwed pregnant teenagers (UPTs). The study involved 34 UPTs from four women's shelters under the supervision of the government and private organizations in Peninsular Malaysia. The respondents were selected using the purposive sampling technique. This study used a quantitative approach, and the instrument of this study was a questionnaire named Tahap Resilien Remaja (TReR), which was administered based on the Ego-Resiliency Scale (ER89) and Connor-Davidson Resilience Scale (CD-RISC). The items in the TReR were validated by five expert evaluators in the psychological and social fields. Study data were analyzed descriptively using Statistical Package for Social Science (SPSS) Version 25.0. The findings of the study showed that UPTs in women's shelters had a moderate level of resilience (Mean[M] = 3.40 , Standard Deviation [SD] = 1.010). The UPTs in this study showed good progress in the shelters. Therefore, the shelters are expected to maintain and improve the quality of existing services from time to time. Other shelters can also utilize the findings of this study to provide better services to their residents to recover from psychosocial problems resulting from cases of unwed pregnancy.
\end{abstract}

Keywords: resilience, teenage, unwed pregnancy, shelter home

\section{Introduction}

The increasing trend of social problems, including extramarital sex among teenagers in Malaysia is becoming more alarming. A survey by the National Health and Morbidity Survey [NHMS] (2017) found that $7.3 \%$ of Malaysian adolescents aged 13-17 have had sex while over $27 \%$ of female teenagers have had sexual intercourse as early as 14 years old (NHMS, 2018). This situation has led to the main problem of UPTs cases. The Ministry of Health Malaysia (MOH) reported that the percentage of UPTs in 2014 was only 25\% and increased to $37 \%$ in 2018 (MOH, 2019). Additionally, unwed pregnancies have also led to the emergence of various social problems such as unsafe abortion, baby dumping, and illegitimate childbirth (Abdul Rahim, 2020; Manzi et al, 2018; Mohd Sukor et al, 2015; Nasir et al., 2016; Saim et al., 2014; Sekh Bidin \& Shaffie, 2020). This problem does not only ruin the future of the country but also the healthy growth of the population in the religious, economic, spiritual, and social aspects as a whole. 
Unwed pregnancy is seen as negative and not well accepted in the Malaysian context (Mohd Suan et al, 2015; Nasir et al., 2016). Previous studies have shown that most UPTs tend to experience trauma and stress (Hayward, 2011; Pallitto et al, 2013; Sedgh et al., 2015), inadequate antenatal care, and an increased risk of death during childbirth (Goshu \& Yitayew, 2019; Vin et al., 2014). Most UPTs are abandoned by parents and friends causing them to abort and dump babies (Wan Ismail, 2012). The number of unsafe abortions has increased by $30 \%$ due to the increase in UPTs (Siraj, 2014). For cases of baby abandonment, the Royal Malaysian Police (RMP) recorded more than 1,010 cases from 2010 to May 2019 and 64\% of the cases confirmed the death of the baby (Hamzah, 2020). From 2019 to January 2020, a total of 25,567 illegal children was recorded by the Malaysian Registry Department (Abdul Rahim, 2020).

Unwed pregnancy does not only have a huge impact on the personal and social development of teenagers but also attracts negative stigma from society for the rest of their lives (Nash et al, 2019; Rosenthal et al, 2014; Sanchez et al, 2010). Teenagers at this stage are still not matured in terms of thinking and behavior in dealing with difficult situations, especially without social support from parents or immediate family (Boobpamala et al., 2019; Nasir et al., 2016). Most of them voluntarily or were forced to be placed in women's shelters until the birth of their child. Entering a shelter without knowing anyone in a new environment is emotionally and physically challenging for them. Only those who can adapt to high difficulties or are resilient can survive from performing worse things (Utami \& Helmi, 2017). Thus, this study aims to identify the level of resilience of UPTs in the women's shelters before childbirth. This study is significant to ensure that UPTs can change for the better emotionally and physically or vice versa. In addition, the programs and services provided at the shelters are expected to help their psychosocial well-being on an ongoing basis before leaving the shelters.

\section{Literature Review}

According to Van Breda (2018), resilience is an output or effect resulting from a vulnerable situation that encompasses various factors, including challenges in the prenatal birth or neonatal period, problems in the family environment, and problems in the wider social environment (such as poverty, crime, or war). Cutter (2016) explains that resilience is an important and indispensable condition in helping build internal and external strengths. Nevertheless, internal and external pressures are always present, and a person's ability to cope with these events is influenced by both successful and unsuccessful adaptations to previous interferences. In some situations, the adaptations or protective factors are ineffective, resulting in a biopsychospiritual disturbance of homeostasis (a person who adapts the body, mind, and spirit to current life conditions) (Connor \& Davidson, 2003). Therefore, Azman (2015) stressed that the concept of resilience or 'fight back' is important for individuals to defend themselves from being easily influenced by a negative or difficult environment and avoid any repetition of negative behavior.

Resilience includes personal qualities that enable a person to thrive in the face of adversities. To deal with various pressures of life today, individuals need to have high self-resilience (Cosden, 2001). Additionally, Mohatt et al. (2008) affirmed that the development or formation of a resilient attitude is important in increasing the effectiveness of the recovery process. It also acts as an inner shield that prevents and protects rather than being influenced by unhealthy elements through good values and moral considerations. However, the idea of resilience envisions a person's general qualities and does not only apply to specific behaviors over a period of time (Block \& Kremen, 1996) because resilience is a unique and fragile process (Taylor et al., 2003). It depends on the extent to which the individual's awareness, understanding, belief, consistency, and ability to survive in any situation or pressure.

Generally, resilience is seen as an individual's ability to prevent, control, adapt, recover, or overcome serious distress after something bad happened in their life (Grotberg, 1995; Luthar et al., 2000; Reivich $\&$ Shatte, 2002). This character can help individuals who are facing problematic situations such as UPTs to manage emotions and judge things better. Indirectly, this situation can protect their mental and physical aspects to hinder them from making wrong decisions in life, such as abortion, baby dumping after giving birth, repeated unwed pregnancy (recidivism), or committing suicide. 


\section{Methodology}

This study used a quantitative approach using a survey of four women's shelters handled by the government and the private organizations in Peninsular Malaysia A total of 34 UPTs from our shelters were selected as respondents using the purposive sampling technique (Creswell \& Creswell, 2018). The respondents were selected based on the characteristics that have been outlined to meet the following study objectives: (i) aged between 14 to 18 years old, (ii) Malaysian citizen, (iii) Malay Muslim, (iv) can communicate in Malay language, (v) first pregnancy due to sexual interaction with a boyfriend or sexual partner by mutual consent, and (vi) was willing and ready to participate with the consent of parents, family members, or caregivers. The involvement of 34 respondents was due to the shortage of respondents because it was based on the actual number of residents when the field study was carried out. The residents in all the shelters are constantly changing due to the process of entering and placing (and leaving) different institutions based on the period of pregnancy, the date of birth of the child, and the period of postpartum.

The data for this study were collected using a questionnaire named Tahap Resilien Remaja (Teenage Resilience Level [TReR]) and were assessed by the researchers based on the Ego-Resiliency Scale (ER89) (Block \& Kremen, 1996) and the Connor-Davidson Resilience Scale (CD-RISC) (Connor \& Davidson, 2003). The content of the TReR questionnaire is divided into two parts: Part A and Part B. Part A is on the respondents' demographic information, namely age, level of education, and length of stay (LOS) in the shelters. Meanwhile, Part B contains 41 items regarding the level of resilience of UPTs who are in the shelters towards their experiences and difficulties. All 41 items in Part B were measured using a Likert scale to measure the attitude and action tendencies that show respondents' resilience using a score from 1 to 5 as follows: strongly disagree (SDi), disagree (D), neither/nor agree (NA), agree (A), and strongly agree (SA).

The TReR questionnaire was originally written in English and translated into Malay language using the back translation method proposed by Brislin (1970). This procedure is important to ensure that the translation process is accurate and does not change the original meaning of the items. Besides that, roundtable discussions involving five appointed experts (from the field of adolescent psychology, social work, sociology, guidance and counseling, and Islamic education) on TReR questionnaire were conducted to provide opportunities for experts to assess and provide feedback on the validity of items in the TReR questionnaire. Before distributing the TReR questionnaire to respondents for the actual study, a pilot study was conducted on 30 respondents (secondary school female students aged 14 to 17 years old) to test the validity and reliability of the TReR questionnaire. Overall, each item in the TReR questionnaire set has a high-reliability value (Cronbach's alpha) $(\alpha=0.90)$. This finding indicated that the instrument used was suitable for measuring the level of UPTs resilience. According to George and Mallery (2003), the reliability coefficient value $>0.8$ and above indicates that the reliability of the newly developed or first used instrument is in a good stage.

The data of this study were analyzed descriptively through the SPSS Version 25.0 software. Descriptive analysis was used to analyze respondents' profiles such as frequency and percent involving mean (M) and standard deviation (SD) to interpret the level of UPTs resilience in women's shelters. The finding is used to answer the research questions. Therefore, the UPTs resilience level was measured based on the mean score and coded into three levels, namely low, moderate, and high levels as shown in Table 1.

Table 1: Mean Score Scale and Interpretation for Resilience Level

\begin{tabular}{ccc}
\hline Mean score & Level & Interpretation of mean score \\
\hline $1.00-2.33$ & Low & Low resilience \\
$2.34-3.66$ & Moderate & Moderate resilience \\
$3.67-5.00$ & High & High resilience \\
\hline
\end{tabular}

Source: Modified from Pallant (2010) 


\section{Ethical Guidelines}

The researchers have received ethics approval from the Department of Social Welfare Malaysia via the letter of statement number: JKMM 100/12/5/2: 2019 / 236 to conduct the study at a government shelter home and an official letter of approval from a private shelter home. Moreover, the researcher obtained consent from caregivers and respondents before the respondents answer the TReR questionnaire.

\section{Result}

This section discusses the results of the finding and is presented in two parts to match the study objectives.

\section{Part 1: Demographic characteristics of the respondents}

This study involved teenage girls who were pregnant without marriage and were residents in the women's shelters. Table 2 shows the results of descriptive analysis for the demographic characteristics of unwed pregnant teenagers focusing on age, education level, and length of stay in the shelter homes. The results of the analysis found that the majority of respondents aged 16 and 17 years old with a total of 9 people (26.5\%) for each age group, while the 15-year-old group consisted of $23.4 \%$ or 8 people. Only 4 respondents $(11.8 \%)$ were 14 and 18 years old, respectively. For the education level, the majority of the respondents were in the secondary school (upper) group with a total of 16 people $(47.1 \%) .15$ respondents or $44.1 \%$ of them have lower secondary school education level, which is only one respondent less than the upper secondary school education level. There were 3 respondents or $8.8 \%$ of them who have primary school education level. For the length of stay at the shelters, the result revealed that 18 respondents or $52.9 \%$ of them stayed for 30 days -3 months. A total of 8 respondents or $23.4 \%$ of them stayed in the shelters for 3 months -6 months, while only $11.8 \%$ (4) of the respondents stayed for 1 day-29 days. In addition, two respondents or $5.6 \%$ of them stayed for more than 2 years. Only 1 respondent (2.9\%) stayed for 6 months- 1 year and 1 year- 2 years, respectively. According to the information provided by the caregivers at the government's shelter home, the respondents who stayed more than 1 year were those who were still bound by the old rules of the shelter home requiring them to stay in the shelter home for 3 years. However, the regulation was amended, where pregnant teenagers may leave the shelter after giving birth to their child due to the accumulating cases of UPTs that caused overcrowding of the shelters.

Table 2: Demographic Characteristics of the Unwed Pregnant Teenagers

\begin{tabular}{lcc}
\hline Demographic & N (34) & Percent (\%) \\
\hline Age (years): & 4 & 11.8 \\
\hline 18 & 4 & 26.5 \\
17 & 9 & 26.5 \\
16 & 8 & 23.4 \\
15 & 4 & 11.8 \\
14 & & \\
\hline Level of education: & 16 & 47.1 \\
\hline Secondary school (upper) & 15 & 44.1 \\
Secondary school (lower) & 3 & 8.8 \\
Primary school & & \\
\hline LOS in the S.H*: & 4 & 11.8 \\
1 day-29 days & 18 & 53.2 \\
30>days-3 months & 8 & 23.4 \\
3>months-6 months & 1 & 2.9 \\
6>months-1 year & 1 & 2.9 \\
1>year-2 years & 2 & 5.8 \\
more than 2 years & & \\
\hline
\end{tabular}


Note. * Length of stay in the shelter home

\section{Part 2: Resilience of the respondents at the women's shelter homes}

The findings of the study in Table 3 show the results of the descriptive analysis regarding the mean score and standard deviation for the level of resilience of UPTs in women's shelters.

Table 3: Mean Score and Standard Deviation of the Resilience of Unwed Pregnant Teenagers

\begin{tabular}{|c|c|c|c|c|c|c|c|c|}
\hline Code & Items & SDi & D & NA & $\mathbf{A}$ & SA & \multirow[t]{2}{*}{$\begin{array}{c}\text { Mean } \\
\text { (M) }\end{array}$} & \multirow{2}{*}{$\begin{array}{c}\text { Standard } \\
\text { Deviation } \\
\text { (SD) }\end{array}$} \\
\hline & & 1 & 2 & 3 & 4 & 5 & & \\
\hline B1 & $\begin{array}{l}\text { I quickly coped after experiencing } \\
\text { the shock } \\
\text { Saya cepat mengatasi selepas } \\
\text { mengalami perasan terkejut }\end{array}$ & 0 & 7 & 17 & 6 & 4 & 3.21 & 0.914 \\
\hline B2 & $\begin{array}{l}\text { I have fun dealing with new } \\
\text { situations } \\
\text { Saya berasa seronok menangani } \\
\text { situasi yang baharu }\end{array}$ & 2 & 9 & 12 & 8 & 3 & 3.03 & 0.857 \\
\hline B3 & $\begin{array}{l}\text { I feel good about dealing with } \\
\text { exceptional situations } \\
\text { Saya berasa seronok menangani } \\
\text { situasi yang luar biasa }\end{array}$ & 3 & 8 & 14 & 6 & 3 & 2.94 & 0.855 \\
\hline B4 & $\begin{array}{l}\text { I always manage to make others feel } \\
\text { impressed with me } \\
\text { Saya selalunya berjaya untuk } \\
\text { menjadikan orang lain berasa } \\
\text { kagum dengan saya }\end{array}$ & 2 & 8 & 18 & 5 & 1 & 2.85 & 0.857 \\
\hline B5 & $\begin{array}{l}\text { I am considered as a person full of } \\
\text { energy } \\
\text { Saya dianggap sebagai seorang } \\
\text { yang penuh bertenaga }\end{array}$ & 2 & 15 & 6 & 7 & 4 & 2.88 & 1.175 \\
\hline B6 & $\begin{array}{l}\text { My curiosity surpasses the curiosity } \\
\text { of most people } \\
\text { Sifat ingin tahu saya melebihi sifat } \\
\text { ingin tahu kebanyakkan orang lain }\end{array}$ & 2 & 9 & 5 & 16 & 2 & 3.21 & 1.095 \\
\hline B7 & $\begin{array}{l}\text { Most of the people I meet are very } \\
\text { pleasant } \\
\text { Kebanyakkan orang yang saya temui } \\
\text { sangat menyenangkan }\end{array}$ & 3 & 9 & 4 & 13 & 5 & 3.24 & 1.257 \\
\hline B8 & $\begin{array}{l}\text { I always think carefully before } \\
\text { taking any action } \\
\text { Saya selalunya berfikir dengan teliti } \\
\text { sebelum mengambil sesuatu } \\
\text { tindakan }\end{array}$ & 0 & 9 & 7 & 14 & 4 & 3.38 & 1.015 \\
\hline B9 & $\begin{array}{l}\text { I love doing new things } \\
\text { Saya suka melakukan perkara- } \\
\text { perkara yang baharu }\end{array}$ & 1 & 4 & 4 & 20 & 5 & 3.71 & 0.970 \\
\hline B10 & $\begin{array}{l}\text { I like to do different things } \\
\text { Saya suka melakukan perkara- } \\
\text { perkara yang berbeza }\end{array}$ & 0 & 8 & 5 & 16 & 5 & 3.53 & 1.022 \\
\hline B11 & $\begin{array}{l}\text { My daily life is full of things that } \\
\text { always satisfy my interests } \\
\text { Kehidupan seharian saya penuh } \\
\text { dengan perkara-perkara yang }\end{array}$ & 0 & 3 & 7 & 18 & 6 & 3.79 & 0.845 \\
\hline
\end{tabular}


sentiasa memenuhi minat saya

\begin{tabular}{|c|c|c|c|c|c|c|c|c|}
\hline B12 & $\begin{array}{l}\text { I am willing to express myself as an } \\
\text { individual with a fairly strong } \\
\text { personality trait } \\
\text { Saya bersedia menyatakan diri saya } \\
\text { sebagai seorang individu yang } \\
\text { mempunyai keperibadian personaliti } \\
\text { yang agak kuat }\end{array}$ & 1 & 8 & 8 & 11 & 6 & 3.38 & 1.129 \\
\hline B13 & $\begin{array}{l}\text { I am pretty quick to forget my } \\
\text { feelings of anger to someone } \\
\text { Saya agak cepat melupakan } \\
\text { perasaan marah saya kepada } \\
\text { seseorang }\end{array}$ & 2 & 15 & 3 & 11 & 3 & 2.94 & 1.179 \\
\hline B14 & $\begin{array}{l}\text { I can adapt to change } \\
\text { Saya boleh menyesuaikan diri } \\
\text { dengan perubahan }\end{array}$ & 0 & 5 & 3 & 21 & 5 & 3.76 & 0.890 \\
\hline B15 & $\begin{array}{l}\text { I feel comfortable with a close } \\
\text { relationship } \\
\text { Saya berasa selesa dengan } \\
\text { hubungan yang rapat. }\end{array}$ & 1 & 2 & 10 & 15 & 6 & 3.68 & 0.945 \\
\hline B16 & $\begin{array}{l}\text { I feel comfortable with a secure } \\
\text { relationship } \\
\text { Saya berasa selesa dengan } \\
\text { hubungan yang terjamin }\end{array}$ & 0 & 3 & 15 & 11 & 5 & 3.53 & 0.861 \\
\hline B17 & $\begin{array}{l}\text { I believe that sometimes God can } \\
\text { help me } \\
\text { Saya percaya bahawa kadang- } \\
\text { kadang Tuhan boleh membantu saya }\end{array}$ & 1 & 0 & 2 & 9 & 22 & 4.50 & 0.862 \\
\hline B18 & $\begin{array}{l}\text { I believe that sometimes fate can } \\
\text { help me } \\
\text { Saya percaya bahawa kadang- } \\
\text { kadang takdir boleh membantu saya }\end{array}$ & 1 & 1 & 4 & 13 & 15 & 4.18 & 0.968 \\
\hline B19 & $\begin{array}{l}\text { I can handle with whatever comes } \\
\text { next } \\
\text { Saya boleh menangani apa sahaja } \\
\text { yang mendatang }\end{array}$ & 2 & 6 & 20 & 5 & 1 & 2.91 & 0.830 \\
\hline B20 & $\begin{array}{l}\text { Past successes give me confidence to } \\
\text { face new challenges } \\
\text { Kejayaan masa lampau memberikan } \\
\text { keyakinan kepada saya untuk } \\
\text { menghadapi cabaran-cabaran } \\
\text { baharu }\end{array}$ & 0 & 0 & 12 & 14 & 8 & 3.88 & 0.744 \\
\hline B21 & $\begin{array}{l}\text { I could see the humor behind } \\
\text { something that happened } \\
\text { Saya dapat melihat kelucuan di } \\
\text { sebalik sesuatu perkara yang } \\
\text { berlaku }\end{array}$ & 3 & 7 & 9 & 13 & 2 & 3.12 & 1.094 \\
\hline B22 & $\begin{array}{l}\text { Dealing with stress makes me a } \\
\text { more resilient person } \\
\text { Menangani stress (tekanan) } \\
\text { menjadikan saya seorang yang lebih } \\
\text { tabah }\end{array}$ & 1 & 4 & 7 & 16 & 6 & 3.65 & 1.012 \\
\hline B23 & $\begin{array}{l}\text { I find it easy to bounce back after an } \\
\text { illness or hardship } \\
\text { Saya mudah untuk bangkit semula }\end{array}$ & 3 & 3 & 7 & 16 & 5 & 3.50 & 1.135 \\
\hline
\end{tabular}


selepas sakit atau kesusahan

Table 3 continued

\begin{tabular}{lllllllll}
\hline B24 I believe that there is wisdom behind & 1 & 0 & 1 & 13 & 19 & 4.44 & 0.824
\end{tabular} something that happened

Saya percaya bahawa ada

hikmahnya di sebalik sesuatu yang berlaku

\begin{tabular}{lllllllll}
\hline B25 I will do my best despite what & 0 & 2 & 8 & 13 & 11 & 3.97 & 0.904
\end{tabular} happens

Saya akan melakukan yang terbaik walaupun apa yang berlaku

B26 I can achieve my goal

Saya boleh mencapai matlamat saya

B27 I did not give up even though the situation was not encouraging Saya tidak berputus asa walaupun keadaan tidak memberansangkan

B28 I know where to get help Saya tahu di mana untuk mendapatkan bantuan

B29 I can think clearly even when under stress

Saya boleh berfikir dengan jelas walaupun berada dalam keadaan tertekan

B30 I prefer to be the leader when solving problems

Saya lebih suka untuk menjadi ketua ketika menyelesaikan masalah

B31 I am not easily discouraged when experiencing failure Saya tidak mudah patah semangat apabila mengalami kegagalan

B32 I consider myself a resilient person Saya menganggap diri saya sebagai seseorang yang tabah

B33 I made decisions that many did not like

Saya membuat keputusan-keputusan yang tidak disukai ramai

B34 I make difficult decisions

Saya membuat keputusan-keputusan yang sukar

B35 I can deal with unpleasant feelings Saya boleh menangani perasaanperasaan yang tidak menyenangkan

B36 I have to act on instinct Saya perlu bertindak mengikut gerak hati

B37 I have a clear direction in life Saya ada arah tuju hidup yang jelas

B38 I was able to take control of my life Saya mampu mengawal kehidupan saya

B39 I like challenges Saya suka menghadapi cabaran-

$\begin{array}{lllllll}0 & 4 & 7 & 15 & 8 & 3.79 & 0.946 \\ 1 & 3 & 5 & 19 & 6 & 3.76 & 0.955\end{array}$

$\begin{array}{lllllll}0 & 3 & 17 & 12 & 2 & 3.38 & 0.739\end{array}$

$\begin{array}{lllllll}4 & 11 & 13 & 3 & 3 & 2.71 & 1.088\end{array}$

1.088


cabaran

\begin{tabular}{|c|c|c|c|c|c|c|c|c|}
\hline B40 & $\begin{array}{l}\text { I strive to achieve my goals } \\
\text { Saya berusaha untuk mencapai } \\
\text { matlamat-matlamat sava }\end{array}$ & 0 & 5 & 4 & 14 & 11 & 3.91 & 1.026 \\
\hline B41 & $\begin{array}{l}\text { I feel proud of my achievements } \\
\text { Saya berasa bangga dengan } \\
\text { pencapaian-pencapaian saya } \\
\text { Oyerall }\end{array}$ & 1 & 4 & 5 & 12 & 12 & 3.88 & 1.122 \\
\hline
\end{tabular}

Note. $\mathrm{SDi}=$ strongly disagree; $\mathrm{D}=$ disagree; $\mathrm{NA}=$ neither/nor agree; $\mathrm{A}=$ agree; $\mathrm{SA}=$ strongly agree

Table 3 shows the 41 resilience items that were tested descriptively. These items aimed to identify the extent of the resilience of UPTs throughout their stay in women's shelters regarding the experiences and difficulties before childbirth. In general, the level of resilience of UPTs was at a moderate level at mean $(M)=3.40$ and standard deviation $(S D)=1.010$. A total of 13 items were at a high level and 28 items were at a moderate level. Although the respondents had a moderate level of resilience, they showed an increase of resilience and good progress throughout their stay in the shelters.

The highest mean value was for item B17, which was "I believe that sometimes God can help me" (M $=4.50, \mathrm{SD}=0.862$ ). Detailed analyses of respondents' views on some items were high for B24: "I believe that there is wisdom behind something that happened" $(\mathrm{M}=4.44)$ and $\mathrm{B} 18$ : "I believe that sometimes fate can help me" $(\mathrm{M}=4.18)$. The mean of the highest moderate item was 3.65 for B22: "Dealing with stress makes me a more resilient person." Based on the analysis, it is explained that the respondents who were placed in the women's shelters were aware of their mistakes and can accept their personal situation. This happened due to the religious activities emphasized by the management, especially the basic knowledge of religion concerning the six pillars of Iman (faith) and the five pillars of Islam as the majority of UPTs are Muslims. However, the shelters should always ensure that each resident knows the basics of Aqidah. In addition, counseling sessions, motivational programs, and various daily activities (such as leisure activities, cooking, baking, and housework) also contributed to the resilience of the respondents. The daily activities can help them reduce the stress of their current situation of unwed pregnancy and reduce the feeling of being confined while in the shelters.

In addition, the results of the study showed that the lowest mean value was for item B34, which was "I make difficult decisions" $(\mathrm{M}=2.29, \mathrm{SD}=1.001)$. This is because most respondents get the support and assistance of their parents and guardians in making important decisions about pregnancy, such as advising against abortion or suicide and finding appropriate shelter to stay. This shows that their parents/guardians are concern about them. Other than that, this situation needs should be focused by the management of the shelter so that the teaching and delivery methods can be diversified to stimulate the development of UPTs' thoughts. Educating and providing knowledge (classes or programs) that can help UPTs think rationally, maturely, and have the ability to make difficult decisions without assistance is necessary, especially after leaving the shelter to avoid repeating the same mistakes.

\section{Discussion}

Resilience is an important need for teenagers who are pregnant out of wedlock in continuing life more positively. Unexpected pregnancy conditions in teenage years have a huge impact on them, especially from the aspect of parental or family acceptance and decision making whether to continue the pregnancy or otherwise. Thus, resilience is important to UPTs in facing various problems as a result of unwed pregnancy. This action is necessary to prevent them from repeating the same act or committing other criminal acts such as suicide, abortion, or baby dumping. Additionally, resilience will calm UPTs in accepting their mistakes, continuing with the pregnancy until childbirth, repenting and deciding on a more prosperous future. The formation of high resilience in UPTs in shelters can indirectly give them hope and the opportunity to rise again to join the mainstream of life in changing the beliefs and perceptions of the society (Saim et al., 2014). 
In line with this, the results of this study revealed that the majority of UPTs in the women's shelters have a good level of resilience. This study found that the construction of resilience of these teenagers occurred throughout the period of pregnancy while they were in the shelters. This behavior may be due to the support and good relationship of UPTs with caregivers and friends (other residents) in the shelters. A study by Olajubu et al. (2021) explained the importance of social support as a positive moderating factor on the stress level of pregnant teenagers. Thus, social support is important as those in the shelters will easily feel depressed and lonely due to being separated from their family for a long period (Nasir et al., 2016; Hayward, 2011).

In addition, the shelter environment plays an important role to increase the resilience level of UPTs. Therefore, the management of each shelter must manage programs and activities that are more systematic and effective in terms of religion, spirituality, motivation, and skills. The findings of this study on the religious and spiritual activities in the shelters can serve as a protective factor that helps UPTs feel calm when experiencing stress. UPTs might experience stress due to extreme guilt over their negative behavior that led to unwed pregnancy. A study by Saim et al. (2014) found that UPTs considered their pregnancy as a punishment for violating religious and cultural laws. Therefore, it is evidenced that resilience is an important component in UPTs in improving their social functioning.

\section{Conclusion}

Resilience acts as a shield to UPTs in preventing and protecting them from continuing to be influenced by negative elements through good values and moral judgments (Mohat et al., 2008; Moe et al., 2007). Grotberg (1995), Luthar et al. (2000), and Reivich and Shatte (2002) mentioned the importance of resilience in individuals to prevent, minimize, adapt, recover, or overcome great suffering after something negatives occurred in their personal lives. The positive situation and environment that UPTs went through in the shelters did affect their personalities. Hence, they might not be aware of their mistakes and change for the better and become resilient (Sekh Bidin \& Shaffie, 2020). It is hoped that the resilience gained while living in the shelters can improve the life of UPTs in terms of education, career, and daily life.

In conclusion, UPT is one of the vulnerable groups that need to be given attention. So, they should be guided to increase their self-resilience during and after leaving the shelter. They are too young to face enormous challenges throughout the pregnancy until the birth process as most of them are rejected and sidelined by their parents or guardians due to their past mistakes. Therefore, the management of the shelter must provide services that meet the psychosocial needs of the UPTs.

\section{Acknowledgment}

This research was supported by the Ministry of Higher Education (MOHE) of Malaysia through Fundamental Research Grant Scheme (FRGS/1/2018/SS06/UUM/02/6).

\section{References}

Abdul Rahim, N. F. (2020, February 20). JPN kaji dasar pendaftaran anak tak sah taraf. Berita Harian Online. $\quad$ https://www.bharian.com.my/berita/nasional/2020/02/657401/jpn-kaji-dasarpendaftaran-anak-tak-sah-taraf.

Azman, A. (2015). The intertwined nature of coping, resilience and hope: A social work perspective. In P. Venkat \& B. M. Bharath (Eds), Some aspects of community empowerment and resilience (pp. 101-109). Allied Publishers Pvt. Ltd.

Block, J., \& Kremen, A. M. (1996). IQ and ego-resiliency: Conceptual and empirical connections and separateness. Journal of Personality and Social Psychology, 70(2), 349-361.

Boobpamala, S., Kongvattananon, P., \& Somprasert, C. (2019). Early management of depression in adolescent pregnancy: An integrative review. The Journal of Behavioral Science, 14(1), 97-113. 
Brislin, R. W. (1970). Back-translation for cross-cultural research. Journal of cross-cultural psychology, 1(3), 185-216.

Connor, K. M., \& Davidson, J. R. (2003). Development of a new resilience scale: The ConnorDavidson resilience scale (CD-RISC). Depression and Anxiety, 18(2), 76-82.

Cosden, M. (2001). Risk and resilience for substance abuse among adolescents and adults with LD. Journal of Learning Disabilities, 34(4), 352-358.

Creswell, J. W., \& Creswell, J. D. (2018). Research design: Qualitative, quantitative and mixed methods approaches (5th ed.). Sage Publications.

Cutter, S. L. (2016). Resilience to what? Resilience for whom?. The Geographical Journal, 182(2), $110-113$.

George, D., \& Mallery, P. (2003). SPSS for Windows step by step: A simple guide and reference. (4th ed.). Allyn \& Bacon.

Goshu, Y. A., \& Yitayew, A. E. (2019). Prevalence and determinant factors of unintended pregnancy among pregnant women attending antenatal clinics of Addis Zemen hospital. Public Library of Science (PloS one), 14(1).

Grotberg, E. H. (1995). A guide to promoting resilience in children: Strengthening the human spirit. Bernard van leer Foundation.

Hamzah, N. (2020, June 26). Baby dumping a serious social concern in Malaysia. The Star. https://www.thestar.com.my/lifestyle/health/2020/06/26/baby-dumping-a-serious-socialconcern-in-malaysia.

Hayward, G. (2011). Teenage pregnancy and its health implications. International Journal of Public Health Research Special Issues, 100-102. https://core.ac.uk/download/pdf/11492346.pdf

Luthar, S. S., Cicchetti, D., \& Becker, B. (2000). The construct of resilience: A critical evaluation and guidelines for future work. Child Development, 71, 543-562.

Manzi, F., Ogwang, J., Akankwatsa, A., Wokali, O. C., Obba, F., Bumba, A., Nekaka, R., \& Gavamukulya, Y. (2018). Factors associated with teenage pregnancy and its effects in Kibuku town council, Kibuku district, Eastern Uganda: A cross sectional study. Primary Health Care, $8(298), 1-6$.

Ministry of Health Malaysia. (2019). Statistik remaja hamil 2014-2018 [Infographic]. http://www.moh.gov.my.

Moe, J., Johnson, J. L., \& Wade, W. (2007). Resilience in children of substance users: In their own words. Substance Use \& Misuse, 42(2-3), 381-398.

Mohatt, G. V., Rasmus, S. M., Thomas, L., Allen, J., Hazel, K., \& Marlatt, G. A. (2008). Risk, resilience, and natural recovery: A model of recovery from alcohol abuse for Alaska Natives. Addiction, 103(2), 205-215.

Mohd Suan, M. A., Ismail, A. H., \& Ghazali, H. (2015). A review of teenage pregnancy research in Malaysia. The Medical Journal of Malaysia, 70(4), 214-219.

Mohd Sukor, N., Sawai, R. P., Mohd Salleh, M. M., Ab Halim, M. A., Baharuddin, D. F., \& Sawai, J. P. (2015). Management of baby dumping in Malaysia: A qualitative study. Al- 'Abqari: Islamic, Social Sciences and Humanities, 6(1), 35-52.

Nash, K., O’Malley, G., Geoffroy, E., Schell, E., Bvumbwe, A., \& Denno, D. M. (2019). "Our girls need to see a path to the future" - Perspectives on sexual and reproductive health information among adolescent girls, guardians, and initiation counselors in Mulanje district, Malawi. Reproductive Health, 16(1), 8.

Nasir, R., Ahmad Zamani, Z., Khairudin, R., Wan Sulaiman, W. S., Mohd Sani, M. N., \& Amin, A. S. (2016). Depression, loneliness and cognitive distortion among young unwed pregnant women in Malaysia: Counselling implications. Asian Social Science, 12(8), 104-109.

National Health and Morbidity Survey. (2018, April). Key findings from the adolescent health and nutrition

surveys. https://iku.moh.gov.my/images/IKU/Document/REPORT/NHMS2017/NHMS2017Infographic. pdf.

Olajubu, A. O., Omoloye, G. O., Olajubu, T. O., \& Olowokere, A. E. (2021). Stress and resilience among pregnant teenagers in Ile-Ife, Nigeria. European Journal of Midwifery, 5, 1-9.

Pallant, J. (2010). SPSS survival manual-A step by step guide to data analysis using SPSS program. (4th ed.). Open University Press. 
Pallitto, C. C., García-Moreno, C., Jansen, H. A., Heise, L., Ellsberg, M., \& Watts, C. (2013). Intimate partner violence, abortion, and unintended pregnancy: Results from the WHO multi-country study on women's health and domestic violence. International Journal of Gynaecology and Obstetrics, 120(1), 3-9.

Reivich, K., \& Shatté, A. (2002). The resilience factor: 7 essential skills for overcoming life's inevitable obstacles. Broadway Books.

Rosenthal, L., Earnshaw, V. A., Lewis, J. B., Lewis, T. T., Reid, A. E., Stasko, E. C., Tobin, J. N., \& Ickovics, J. R. (2014). Discrimination and sexual risk among young urban pregnant women of colour. Health Psychology, 33(1), 3-10.

Saim, N. J., Dufåker, M., \& Ghazinour, M. (2014). Teenagers' experiences of pregnancy and the parents' and partners' reactions: A Malaysian perspective. Journal of Family Violence, 29,465472.

Sanchez, N., Grogan-Kaylor, A., Castillo, M., Caballero, G., \& Delva, J. (2010). Sexual intercourse among adolescents in Santiago, Chile: A study of individual and parenting factors. Revista Panamericana de Salud Pública, 28(4), 267-274.

Sedgh, G., Finer, L. B., Bankole, A., Eilers, M. A., \& Singh, S. (2015). Adolescent pregnancy, birth, and abortion rates across countries: Levels and recent trends. Journal of Adolescent Health, 56(2), 223-230.

Sekh Bidin, M. S., \& Shaffie, F. (2020). Preliminary study of unmarried pregnant female adolescents: Are they able to build resilience? Borneo International Journal, 2(3), 1-6.

Siraj, H. H. (2014). Pengguguran: Sosial dan kesihatan. Health Education Division, Ministry of Health Malaysia. http://www.infosihat.gov.my.

Taylor, E. R., Karcher, M. J., Kelly, P. J., \& Valescu, S. (2003). Resiliency, risk, and substance use among Hispanic urban juvenile detainees. Journal of Addictions \& Offender Counseling, 24(1), 46-64.

Utami, C. T., \& Helmi, A. F. (2017). Self-Efficacy dan resiliensi: Sebuah tinjauan meta-analisis. Buletin Psikologi, 25(1), 54-65.

Van Breda, A. D. (2018). A critical review of resilience theory and its relevance for social work. Social Work, 54(1), 1-18.

Vin, S. X., Muhammad, N. A., Sun, T. P., Meng, K. T. T., Tohid, H., \& Omar, K. (2014). Physical and psychosocial impacts of pregnancy on adolescents and their coping strategies: A descriptive study in Kuala Lumpur, Malaysia. Malaysian Journal of Public Health Medicine, 14(3), 71-80.

Wan Ismail, W. F. (2012, December 20). Effects \& consequences of teenage pregnancy. MyHealth: Ministry of Health Malaysia. http://www.myhealth.gov.my/en/effects-a-consequencesofteenage-pregnancy. 